\title{
The Effect of Temperature on Operator's Working Time the Assembly Section at PT. FGH
}

\author{
Darsini \\ Universitas Veteran Bangun Nusantara \\ Sukoharjo, Indonesia \\ dearsiny@yahoo.com
}

\begin{abstract}
PT. FGH is a manufacturing industry engaged in the processing of wood from raw materials to semi-finished or directly into finished materials. The products produced are products of tables, chairs, cabinets and wooden doors. In its production the physical environment will affect humans in the work. Temperature is one of the environmental factors that can affect human performance of the production. The temperature in the room where you work will affect the comfort that can cause disruption of attention to heat and body balance. Excess heat in the body can cause drowsiness, can also reduce stability and of course the error rate will be more, so the time spent will be longer.

This research was conducted at PT. FGH with simulation, observation and directly see the effect of low temperature level treatment $(180 \mathrm{C}-200 \mathrm{C})$, medium $(240 \mathrm{C}$ $270 \mathrm{C})$ and high $(300 \mathrm{C}-320 \mathrm{C})$ on operator working time in folding computer desk assembly. Observations were made 10 times each treatment. Analysis of the data used is by ANAVA with F statistical test and Least Significance Different (LSD) test with a significance level of $5 \%$. From the results of research and processing of data obtained results that there is a significant effect of each treatment between temperatures. The best completion time in assembly is at medium temperature with the smallest average assembly time.
\end{abstract}

Keywords: anov, assembly, temperature, working time

\section{INTRODUCTION}

Companies generally produce products and services whose purpose is to earn profits and maintain their lives. For this reason, the company must be able to see and take advantage of the opportunities that exist, so that it can assess the possibilities and opportunities that might occur in the future. In addition, the products produced must want to increase and with higher quality as well. Product quality is certainly influenced by factors of production, both from internal and external companies. Internal factors such as production processes, engine conditions, labor conditions, work environment conditions and equipment used, while external factors of the company are influenced by external environmental conditions and raw materials obtained from nature, external factors are also influenced by how production is distributed.

The fact is that the work environment influences human work (labor). Humans are able to carry out their activities properly, if supported by a good environment, so that an optimal result is achieved. One of the factors that influence the human ability to work is the work environment factors, namely all the conditions that are found around the workplace, for example, lighting, temperature (temperature), noise, ventilation, etc. that significantly influence human work.

Based on the previous research conducted by [1], regarding noise and heat stress with a feeling of work exhaustion in the workforce, states that heat pressure is one of the factors causing feelings work fatigue felt by the workforce. In addition, the effect of heat stress also affects the health of workers.

Temperature is also called temperature is a measure of the heat-coldness of an object and condition, which is one of the factors that influence a person's ability to carry out work activities. In this case it will affect the work of the operator. Extreme rates or temperatures are excessive heat and cold, which can interfere with work and health. The temperature unit in Indonesia is 0C (degrees Celsius), while the unit of measure that is widely used abroad is degrees Fahrenheit.

Based on the above description and this problem, the research that will be carried out is how to influence the temperature of the assembly operator's working time at PT. FGH.

\section{LITERATURE REVIEW}

\section{A. Ergonomics}

Ergonomics is science, technology and art or with a multidisciplinary approach to harmonize the tools, ways and work environment to the capabilities and limitations of humans, so that working conditions and work environments that are healthy, safe, comfortable and efficiencies can be achieved, and also can achieve the highest productivity [2]. Ergonomics is also called human factor engineering. [3] formulated that, ergonomics is a systematic knowledge system to utilize information about the nature, abilities and limitations of humans to design a workable system so that people can live and work on the system properly to achieve goals desired through the job effectively, safely and comfortably.

Ergonomics according to [4] is a scientific discipline that studies humans in relation to work. Ergonomics is the study of the human aspects of the work environment which are reviewed in anatomy, physiology, psychology, engineering management and design or design [5].

In employment, ergonomics has a large role, almost all types of work always use ergonomics. Ergonomics is applied in the world of work so that workers feel comfortable doing the work. With this sense of comfort, it is beneficial to work productivity that is expected and able to increase. In general, existing ergonomic 
definitions discuss the problems of the relationship between human workers and their tasks and work and the design of the objects they use [6].

\section{B. Temperature}

Understanding temperature is a measure of the cold or heat of a situation or something else. Temperature definition is a measure of the average kinetic energy of a molecule. If the temperature is high, the average kinetic energy will be large. The hotter the object, the higher the value of the degree, on the contrary the cooler the object, the lower the value of the degree.

The human body will always try to maintain a normal state with a perfect body system so that it can adjust to the changes that occur outside the body. But the ability to adjust itself to outside temperature is if changes in the outside body temperature do not exceed $20 \%$ of normal conditions for heat conditions and $35 \%$ for cold conditions. All of this is from the normal state of the body. In normal circumstances, each member of the human body has different temperatures.

Indoor climate is the physical condition around which work is carried out. The principal components in this temperature are (a) air temperature; (b) ergonomics on the surrounding surface; (c) air humidity; and (d) Air movement.

\section{Comfort}

Comfort or often called comfort is a condition of fulfilling basic human needs, namely the need for peace (a satisfaction that enhances the everyday appearance), needs have been fulfilled and a state of peace. A comfortable and ideal work environment is a situation where workers have experience not experiencing stress. A comfortable condition is in a neutral area, where the body does not need action to keep the heat conditions in balance. Comfortable environment temperature is in the range of $250 \mathrm{C}-270 \mathrm{C}$ for humans who rest.

To carry out its activities in the room to be carried out properly, humans need certain physical conditions in the vicinity that are considered comfortable. One of the requirements of a comfortable physical condition is the comfortable temperature, which is the thermal condition of the air in the room that does not disturb his body. A room temperature that is too low will cause cold or shivering, so the ability to move down. Meanwhile, high room temperature will cause overheating and sweating, thus disrupting activities as well. It can be said that working conditions will decrease or not maximum in uncomfortable air conditions [7].

A person's discomfort at work can make a disturbance or even cause psychological effects or one of physiological pain. A person's discomfort at work will result in functional changes in the organs of the human body. For example, excessive heat conditions will cause fatigue and drowsiness, reduce stability and also increase work errors. Conversely, if excessive cold conditions will lead to feeling lazy, which will reduce concentration, especially with work that requires mental readiness.
In determining the convenience scale that is with a seven-point scale whose objectives relate to the work environment with defined as follows:

1. Very too cold: $170 \mathrm{C}$

2. Too cold: $200 \mathrm{C}$

3. Comfortable cold: $230 \mathrm{C}$

4. Comfortable: $260 \mathrm{C}$

5. Comfortable heat: $290 \mathrm{C}$

6. Too hot: $320 \mathrm{C}$

7. Very too hot: $350 \mathrm{C}$

\section{RESEARCH METHODOLOGY}

\section{A. Place and Object of Research}

The research was carried out in the FHG company which is located at Carikan, Sukoharjo is a manufacturing industry engaged in the processing of wood from raw materials to semi-finished or directly into finished materials. The superior production made is the product of wooden doors, chairs, cabinets and tables. As an object of research for folding computer desks, the goal is to determine the level of temperature in the work of the operator in the folding computer desk assembly. The number of workers is 10 people in the assembly section and is assumed to have normal working ability. Workers do work with low temperatures (180C - 200C), medium temperatures $(240 \mathrm{C}-270 \mathrm{C})$ and high temperatures $(300 \mathrm{C}-320 \mathrm{C})$. While the object of research is the assembly of folding tables for learning as much as 10 operators with different temperature conditions.

\section{B. Tools used}

Computer desk assembly, a tool used to measure time by using a stop watch

\section{RESULTS AND DISCUSSION}

\section{A. Data collection and processing}

This research is assumed for other environmental conditions such as noise, lighting is considered normal.

The following is a picture of the production of a folding computer desk:

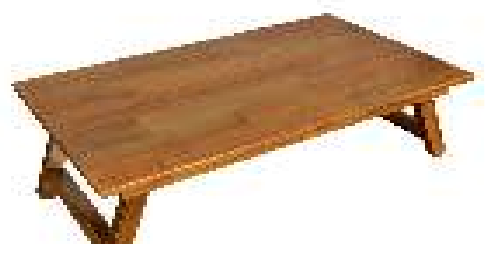

Figure 1. The folding computer desk looked up

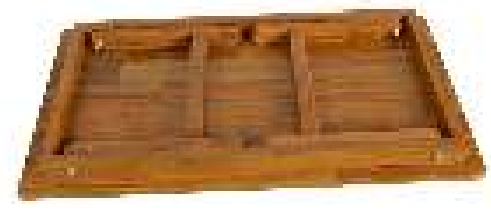

Figure 2. The folding computer desk looks from the bottom 
TABLE 1. WORK COMPLETION TIME (MINUTES)

\begin{tabular}{|ccccccccccccc|}
\hline Treatment & 1 & 2 & 3 & 4 & 5 & 6 & 7 & 8 & 9 & 10 & total $\begin{array}{c}\text { Aver } \\
\text { age }\end{array}$ \\
\hline $18^{\circ} \mathrm{C}-20^{\circ} \mathrm{C}$ & 21 & 20 & 21 & 20 & 20 & 20 & 21 & 21 & 20 & 20 & 204 & 20,4 \\
\hline $24^{\circ} \mathrm{C}-27^{\circ} \mathrm{C}$ & 19 & 18 & 19 & 20 & 19 & 19 & 19 & 18 & 19 & 19 & 189 & 18,9 \\
\hline $30^{\circ} \mathrm{C}-32^{\circ} \mathrm{C}$ & 22 & 21 & 22 & 21 & 21 & 23 & 22 & 23 & 22 & 22 & 219 & 21,9 \\
\hline Total & 62 & 59 & 62 & 61 & 60 & 62 & 62 & 62 & 61 & 61 & 612 & 61,2 \\
\hline $\begin{array}{c}\text { Many } \\
\text { observatio } \\
\text { ns }\end{array}$ & 3 & 3 & 3 & 3 & 3 & 3 & 3 & 3 & 3 & 3 & & \\
\hline \begin{tabular}{c} 
Average \\
\hline
\end{tabular} & 20,7 & $\begin{array}{c}19, \\
7\end{array}$ & $\begin{array}{c}20, \\
7\end{array}$ & $\begin{array}{c}20, \\
3\end{array}$ & $\begin{array}{c}20, \\
0\end{array}$ & $\begin{array}{c}20, \\
7\end{array}$ & $\begin{array}{c}20, \\
7\end{array}$ & $\begin{array}{c}20, \\
7\end{array}$ & $\begin{array}{c}20, \\
3\end{array}$ & $\begin{array}{c}20, \\
3\end{array}$ & $\begin{array}{c}204, \\
0\end{array}$ & \\
\hline
\end{tabular}

\section{B. Data analysis}

Data analysis was performed by the smallest $F$ and Real Difference Test (BNt) or better known as the LSD (Least Significance Different) Test, this method as a reference in determining whether the average treatment was statistically different or not. The smallest real difference value is needed for some data from the previous variance analysis (ANOVA) calculation. F test and LSD test were carried out with a real level of 5\%, obtained the $\mathrm{F}$ table value $=3.35 \mathrm{LSD}$ value $=6.12$, the results of the analysis are as follows:

1. Ho $=\mu_{1}=\mu_{2}=\mu_{3}=\mu_{4}=\mu_{5}=\mu_{6}=\mu_{7}=\mu_{8}=\mu_{9}=$ $\mu_{10}$

2. Total Sum of Squares (jumlah kuadrat keseluruhan)

3. $\mathrm{SST}=12.540$

4. Total Sum of Squares average

5. $\mathrm{Ry}=\mathrm{JK}^{2} / \mathrm{k} \cdot \mathrm{n}=12.484,80$

6. Total Sum of Squares Treatment

7. $P y=3,20$

8. Error Sum of Square (Jumlah Kuadrat Error) $\mathrm{SSE}=\mathrm{EY}=\mathrm{SST}-\mathrm{Ry}-\mathrm{Py}$

$$
\begin{aligned}
& =12.540-12.484 .80-3,20 \\
& =52
\end{aligned}
$$

TABLE 2. RESULTS OF TREATMENT ANAVA

\begin{tabular}{cccccc}
\hline $\begin{array}{c}\text { Source of } \\
\text { Variation }\end{array}$ & DB & $\begin{array}{c}\text { Kumlah } \\
\text { Kuadrat } \\
J K\end{array}$ & $\begin{array}{c}J K \text { Rata- } \\
\text { rata }\end{array}$ & $F_{\text {Tabel }}$ & $F_{\text {Hitung }}$ \\
\hline Average & 1 & $12.484,80$ & $12.484,80$ \\
Treatment & 2 & 3,20 & 1,60 & 3,35 & 0,83 \\
Mistake & 27 & 52,00 & 1,93 & & \\
\hline A. Total & B. 30 & C. $12.540,00$ & D. & $E$. & $F$. \\
\hline
\end{tabular}

\section{DISCUSSION}

From table 2 above it is obtained that $F_{\text {hitung }}<F_{\text {tabel }}$ which means that overall shows no significant effect of the three treatments between low, medium and high temperatures in the work of the assembly part operator.

\section{CONCLUSION}

Based on the description above that because $F_{\text {hitung }}<F_{\text {tabel }}$ $\rightarrow \mathrm{F}=0,83$ is smaller than 3.34 then the null hypothesis is accepted. This means that the three treatments of temperature giving (low, medium and high) given to 10 laborers of folding computer desk assembly parts have the same effect, to be exact not significantly different, to the treatment of giving temperature (low, medium and high). Of the three treatments, giving the temperature the same effect on the results of folding computer assembly.

\section{REFERENCES}

[1] Novena Ayu Parasti, Chandra Dewi K., D. R. T. D. Analisis Postur Kerja Pada Industri Gerabah, (43), 63-72, 2013.

[2] Manuaba, A, 1998, Bunga Rampai Ergonomi, Vol.1, Program Studi S2 Ergonomi Fisiologi Kerja, UNUD.

[3] Sutalaksana, Iftikar, Teknik Tata Cara Kerja, Institut Teknologi Bandung, Bandung, 1979.

[4] Sritomo Wignjosoebroto, Ergonomi Studi Gerak dan Waktu, Guna Widya, Jakarta, 2000.

[5] Eko Nurmianto, Ergonomi Konsep dan Aplikasinya, Guna Widya, Jakarta, 1998.

[6] Tarwaka, Bakri, S. H. A., \& Sudiajeng, L. Ergonomi untuk Keselamatan, Kesehatan Kerja dan Produktivitas. Retrieved from http://shadibakri.uniba.ac.id/wp-content/uploads/2016/03/BukuErgonomi.pdf, 2004.

[7] Rilatupa, J. Aspek Kenyamanan Termal Pada Pengkondisian Ruang Dalam. Sains Dan Teknologi EMAS, 18(3), 191-198, 2008. 